\title{
Appraisal of Cumulative Volume of Biogas Produced from Water Hyacinth and Selected Animal Dungs Co-Digestion Mixes
}

\author{
Ochuko M. Ojo ${ }^{\star 凶}$, and Josiah O. Babatola \\ Department of Civil Engineering, the Federal University of Technology, Akure, PMB 704, Ondo State, Nigeria \\ ${ }^{\star}$ Corresponding author’s email: omojo@ futa.edu.ng; (D) ORCiD: 0000-0002-1113-0359
}

\begin{abstract}
Water Hyancinth (WH) was co-digested with different mix ratios of poultry manure (PM), cow dung (CD) and pig dung (PD). A comparative analysis of the cumulative volume of gas produced from the different co-digestion mixes was carried out. The monitoring of the digestion process was done on a daily basis for a retention period of 40 days. The efficacy of the digestion process as well as the best mix ratio of water hyacinth to the different animal dungs was also evaluated in terms of the volume of gas produced. A rotameter with a capacity of 0.1-1L/Min equipped with a measuring tube was used for the gas flow measurements. From the results obtained the best mix of the PDaided WH digestion is $3 \mathrm{WH}: 7 \mathrm{PD}$ while $\mathrm{CD}$ - aided WH digestion is $2 \mathrm{WH}: 8 \mathrm{CD}$ and PM-aided WH digestion is 2 WH: 8 PM. The study also revealed that the PM-aided WH mix produced more biogas compared to the CD-aided and PD-aided WH digestion mix.
\end{abstract}

Keywords: Co-digested, comparative, cumulative, digestion, biogas.

\section{INTRODUCTION}

Water hyacinth (WH) cause ecological and economic problems by impeding navigation and fishing activities, clogging irrigation systems and by creating a chronic shortage of dissolved oxygen harmful to the fauna and the flora (Malik, 2007). Perna and Burrows (2005) noted that the water hyacinth covers on water bodies reduce the gaseous exchanges that take place at the air/water interface and reduce the photosynthetic activity of submerged plants by hindering the penetration of the sun's rays.

Biogas consists primarily of exploitable methane $\left(\mathrm{CH}_{4}\right)$ and passive carbon dioxide $\left(\mathrm{CO}_{2}\right)$, which are both colourless and odourless. Methane has 20 times more greenhouse gas potential than carbon dioxide, so the capture and burning of methane significantly reduces the greenhouse gas effect (Atkins et al., 2008). Depending on the source of the organic matter and the management of the anaerobic digestion process, small amounts of other gases may be present (Arogo et al., 2009)

Several authors have confirmed the possibility of producing biogas from WH (Katima, 2001; Kivaisi and Mtila, 1997; Patil et al., 2011, Ojo, 2017, Ojo et al., 2018). These studies highlight that $\mathrm{WH}$ can produce as much as 20.3 liters of biogas per $\mathrm{kg}$ of dry matter.
These researches concluded that aquatic plants generate high-quality biogas. Pachaiyappan et al. (2014) worked on biogas production from water hyacinth blended with cow dung using different combinations and found out that encouraging results were obtained with a combination of 50\% water hyacinth and 50\% cow dung. Water hyacinth generates biogas that has greater methane content and more soil nutrients than digested dung.

Anaerobic digestion that utilizes manure for biogas production is one of the most promising uses of biomass wastes because it provides a source of energy while simultaneously resolving ecological and agrochemical issues (Budiyono et al., 2010). Animal waste such as cow dung and poultry wastes are familiar feed stooks used in the production of biogas. Several authors have worked on the potential of producing biogas from animal wastes (Itodo and Kucha, 1998; Sadaka and Engler, 2000; Bujoczek et al., 2000; Castrillon et al., 2002; Kivaisi, 2002; Gelegenis et al., 2007, Ojolo et al., 2007, Li et al., 2009; Budiyono et al., 2010; Ofoefule et al., 2010; Yusuf et al., 2011, Nnabuchi et al., 2012). The co-digestion of these familiar feedstocks with less familiar feedstocks, i.e., water hyacinth is imperative. 
Co-digestion refers to the anaerobic digestion (AD) of multiple biodegradable substrates (feedstocks) in an $\mathrm{AD}$ system. Co-digestion is a technology that is increasingly being applied for simultaneous treatment of different solid and liquid organic wastes (Bouallagui et al., 2009). The general idea is to maximize the production of biogas in an $\mathrm{AD}$ plant by adding substrates that produce much more biogas per unit mass than the base substrate. AD is a well establish technology for manure and wastewater treatment and it can produce renewable energy, reduce organic and pathogen content, and create a stable residual waste that can be used as soil fertilizer. However, some manures present problems such as a high solids content or inhibition by toxic compounds released in the process. Codigestion can not only reduce these problems, but also could improve the overall performance (Zamudio, 2010). Al-Imam et al. (2013) analysed and compared biogas from cow dung, poultry waste and water hyacinth but did not carry out a co-digestion of the different feed stocks. It was observed from that study that biogas production from cow dung, poultry waste and water hyacinth is $0.034 \mathrm{~m}^{3} / \mathrm{kg}$, $0.058 \mathrm{~m}^{3} / \mathrm{kg}$ and $0.014 \mathrm{~m}^{3} / \mathrm{kg}$ respectively. Adegunloye et al. (2013) investigated the ratio variation of $\mathrm{WH}$ on the production of biogas using pig dung. However, the blended water hyacinth and pig dung was only weighed in ratio $1: 1$ and $1: 3$.

\section{MATERIALS AND METHODS}

\section{Substrates sources}

Substrates utilized in this research are water hyacinth (WH), poultry manure (PM), cow dung (CD) and pig dung (PD). WH was harvested from a private pond in Akure, Ondo State, while PM, CD and PD were collected from the animal farm of the Federal University of Technology, Akure. Fresh water hyacinth (leaves, stem and root) on collection was chopped to small sizes of about $2 \mathrm{~cm}$. The feedstocks were appropriately weighed.

31 mix ratios of $\mathrm{WH}$ to the $\mathrm{PM}, \mathrm{CD}$ and $\mathrm{PD}$ were evaluated as shown in Table 1.

Table 1. Mix ratios of WH- animal dung aided feed stocks

\begin{tabular}{lllll}
\hline $10 \mathrm{WH}$ & $9 \mathrm{WH}: 1 \mathrm{PD}$ & $8 \mathrm{WH}: 2 \mathrm{PD}$ & $7 \mathrm{WH}: 3 \mathrm{PD}$ & $6 \mathrm{WH}: 4 \mathrm{PD}$ \\
5WH:5PD & $4 \mathrm{WH}: 6 \mathrm{PD}$ & $3 \mathrm{WH}: 7 \mathrm{PD}$ & $2 \mathrm{WH}: 8 \mathrm{PD}$ & $1 \mathrm{WH}: 9 \mathrm{PD}$ \\
10PD & $9 \mathrm{WH}: 1 \mathrm{CD}$ & $8 \mathrm{WH}: 2 \mathrm{CD}$ & $7 \mathrm{WH}: 3 \mathrm{CD}$ & $6 \mathrm{WH}: 4 \mathrm{CD}$ \\
5WH:5CD & $4 \mathrm{WH}: 6 \mathrm{CD}$ & $3 \mathrm{WH}: 7 \mathrm{CD}$ & $2 \mathrm{WH}: 8 \mathrm{CD}$ & $1 \mathrm{WH}: 9 \mathrm{CD}$ \\
10CD & $9 \mathrm{WH}: 1 \mathrm{PM}$ & $8 \mathrm{WH}: 2 \mathrm{PM}$ & $7 \mathrm{WH}: 3 \mathrm{PM}$ & $6 \mathrm{WH}: 4 \mathrm{PM}$ \\
5WH:5PM & $4 \mathrm{WH}: 6 \mathrm{PM}$ & $3 \mathrm{WH}: 7 \mathrm{PM}$ & $2 \mathrm{WH}: 8 \mathrm{PM}$ & $1 \mathrm{WH}: 9 \mathrm{PM}$ \\
\cline { 2 - 5 } $10 \mathrm{PM}$ & & & &
\end{tabular}

The monitoring of the digestion process was done on a daily basis for a retention period of 40 days. The temperature within the digester was measured using a mercury thermometer calibrated in degree centigrade while the $\mathrm{pH}$ was determined using a $\mathrm{pH}$ meter. The efficacy of the digestion process as well as the best mix ratio of water hyacinth to the different animal dungs was also evaluated in terms of the volume of gas produced. A rotameter was used to measure the rate of flow of the gas while a manometer was used to measure the pressure of the gas.

A rotameter flowmeter of model LZM-4T with a capacity of $0.1-1 \mathrm{~L} / \mathrm{Min}$ equipped with a measuring tube was used for the gas flow measurements. When the gas from the digester was introduced into the tube, the float was lifted from its initial position at the inlet, allowing the fluid to pass between it and the tube wall. As the float rose, more biogas passed by the float because the tapered tube's diameter was increasing. Ultimately, a point was reached where the flow area was large enough to allow the entire volume of the gas to flow past the float. This position corresponds to a point on the tube's measurement scale and provides an indication of the biogas flow rate.

The equation for the biogas flow rate was calculated using the ideal gas equation which is given in equation 1:

$$
\frac{P_{1} V_{1}}{T_{1}}=\frac{P_{2} V_{2}}{T_{2}}
$$

The gas flow rate was calculated from equation 2:

$$
V_{2}=\frac{P_{1} V_{1} T_{2}}{P_{2} T_{1}}
$$

$\mathrm{V}_{1}=$ rotameter reading (normal liters per minute)

$\mathrm{V}_{2}=$ actual flow rate (liters per minute)

$\mathrm{P}_{1}=$ pressure at normal conditions

$\mathrm{P}_{2}=$ actual pressure

$\mathrm{T}_{1}=$ air temperature at normal conditions

$\mathrm{T}_{2}=$ actual temperature of air

The normal conditions used were 0 degrees Celsius $\left(273.15^{\circ} \mathrm{K}\right)$ and 1 atmosphere (1.01325 bar)

\section{Data analysis}

A multiple regression analysis was carried out to examine the determinants of cumulative volume of gas produced from the three best mixes of the animal dung aided with WH digestion

The regression equation is described by equations 3 and 4 
$\mathrm{Y}=\mathrm{f}\left(\mathrm{X}_{1}, \mathrm{X}_{2}, \mathrm{X}_{3}, \mathrm{X}_{4}, \mathrm{E}\right) \ldots \ldots \ldots$....(3)

$\mathrm{Y}=\mathrm{B}_{0}+\mathrm{B}_{1} \mathrm{X}_{1}+\mathrm{B}_{2} \mathrm{X}_{2}+\mathrm{B}_{3} \mathrm{X}_{3}+\mathrm{B}_{4} \mathrm{X}_{4}+\mathrm{E}$

Where $\mathrm{Y}$ is the cumulative volume of gas

$\mathrm{B}_{0}$ is the constant term

$B_{i}$ 's ( $i=1$ to 4$)$ are coefficients of the independent variable

$\mathrm{X}_{1}$ is the Retention time (days)

$\mathrm{X}_{2}$ is the Hydrogen ion concentration $(\mu \mathrm{mol} / \mathrm{L})$

$\mathrm{X}_{3}$ is the Temperature $\left({ }^{\circ} \mathrm{C}\right)$

$\mathrm{X}_{4}$ is the biogas pressure (bar)

$\mathrm{E}$ is the error term

The null hypothesis $\left(H_{0}\right)$ and alternative hypothesis $\left(H_{1}\right)$ of the significance test for correlation were expressed in the following ways for the two-tailed test.

$H_{0}: \rho=0$ (the correlation coefficient is 0 ; there is no association between the determinants of biogas production)

$H_{1}: \rho \neq 0$ (the correlation coefficient is not 0 ; a nonzero correlation could exist)

\section{RESULTS AND DISCUSSION}

\section{Cumulative biogas yield}

The cumulative volume of biogas produced for the different mix ratios is presented in Table 2. The cumulative biogas yield for single-substrate digestion is shown in Figure 1. The results showed that WH singlesubstrate digestion produced a cumulative gas volume of $32.18 \mathrm{~L}$ which corresponds to $5.14 \mathrm{~L} / \mathrm{kg}$ of $\mathrm{WH}$, PD single-substrate digestion produced a cumulative gas volume of $94.47 \mathrm{~L}$ corresponding to $15.1 \mathrm{~L} / \mathrm{kg}$ of $\mathrm{PD}$. Similarly, CD produced a cumulative gas volume of 126.95 L, corresponding to $20.3 \mathrm{~L} / \mathrm{kg}$ of $\mathrm{CD}$, while $\mathrm{PM}$ produced a cumulative gas volume of $209 \mathrm{~L}$ corresponding to $33.58 \mathrm{~L} / \mathrm{kg}$ of PM.

Figure 2 illustrates the cumulative biogas yield for PD-aided WH digestion. The results revealed a range of $37.54-140.32 \mathrm{~L}$ for the cumulative volume of biogas produced. $3 \mathrm{WH}$ : $7 \mathrm{PD}$ had the highest cumulative gas volume of $140 \mathrm{~L}$ which corresponds to $22.45 \mathrm{~L} / \mathrm{kg}$.

Figure 3 portrays the cumulative Biogas yield for CDaided WH digestion. The results showed a range of 53.18 - $141.72 \mathrm{~L}$ with $2 \mathrm{WH} 7 \mathrm{CD}$ recording the highest value corresponding to $22.68 \mathrm{~L} / \mathrm{kg}$.
The cumulative biogas yield for PM-aided $\mathrm{WH}$ digestion is shown in Figure 4. The results revealed a range of $54.45-216.55 \mathrm{~L}$ with $2 \mathrm{WH}$ : 8 PM recording the highest value corresponding to $34.65 \mathrm{~L} / \mathrm{kg}$.

Table 2. Cumulative volume of biogas produced for the different mix ratios

\begin{tabular}{|c|c|c|}
\hline $\mathbf{S} / \mathbf{N}$ & Mix ratio & $\begin{array}{c}\text { Cumulative Volume of } \\
\text { biogas produced } \\
\text { (litres) }\end{array}$ \\
\hline 1 & $10 \mathrm{WH}$ & 32.18 \\
\hline 2 & 9WH: 1PD & 37.55 \\
\hline 3 & 8WH: 2PD & 54.32 \\
\hline 4 & 7WH: 3PD & 64.32 \\
\hline 5 & $6 \mathrm{WH}: 4 \mathrm{PD}$ & 78.54 \\
\hline 6 & 5WH: 5PD & 102.93 \\
\hline 7 & 4WH: 6PD & 117.33 \\
\hline 8 & 3WH: 7PD & 140.32 \\
\hline 9 & $2 \mathrm{WH}: 8 \mathrm{PD}$ & 124.04 \\
\hline 10 & 1WH: 9PD & 119.13 \\
\hline 11 & 10PD & 95.47 \\
\hline 12 & $9 \mathrm{WH}: 1 \mathrm{CD}$ & 53.18 \\
\hline 13 & $8 \mathrm{WH}: 2 \mathrm{CD}$ & 67.05 \\
\hline 14 & $7 \mathrm{WH}: 3 \mathrm{CD}$ & 81.04 \\
\hline 15 & $6 \mathrm{WH}: 4 \mathrm{CD}$ & 89.31 \\
\hline 16 & $5 \mathrm{WH}: 5 \mathrm{CD}$ & 99.29 \\
\hline 17 & 4WH:6CD & 116.38 \\
\hline 18 & $3 \mathrm{WH}: 7 \mathrm{CD}$ & 128.12 \\
\hline 19 & $2 \mathrm{WH}: 8 \mathrm{CD}$ & 141.72 \\
\hline 20 & 1WH:9CD & 132.78 \\
\hline 21 & $10 \mathrm{PM}$ & 126.95 \\
\hline 22 & $9 \mathrm{WH}: 1 \mathrm{PM}$ & 54.46 \\
\hline 23 & 8WH:2PM & 70.06 \\
\hline 24 & 7WH:3PM & 85.17 \\
\hline 25 & $6 \mathrm{WH}: 4 \mathrm{PM}$ & 100.64 \\
\hline 26 & 5WH:5PM & 117.23 \\
\hline 27 & 4WH:6PM & 133.54 \\
\hline 28 & 3WH:7PM & 169.54 \\
\hline 29 & $2 \mathrm{WH}: 8 \mathrm{PM}$ & 216.55 \\
\hline 30 & 1WH:9PM & 164.09 \\
\hline 31 & $10 \mathrm{PM}$ & 209.90 \\
\hline
\end{tabular}

WH: water hyacinth; PM: poultry manure; CD: cow dung; PD: pig dung. 


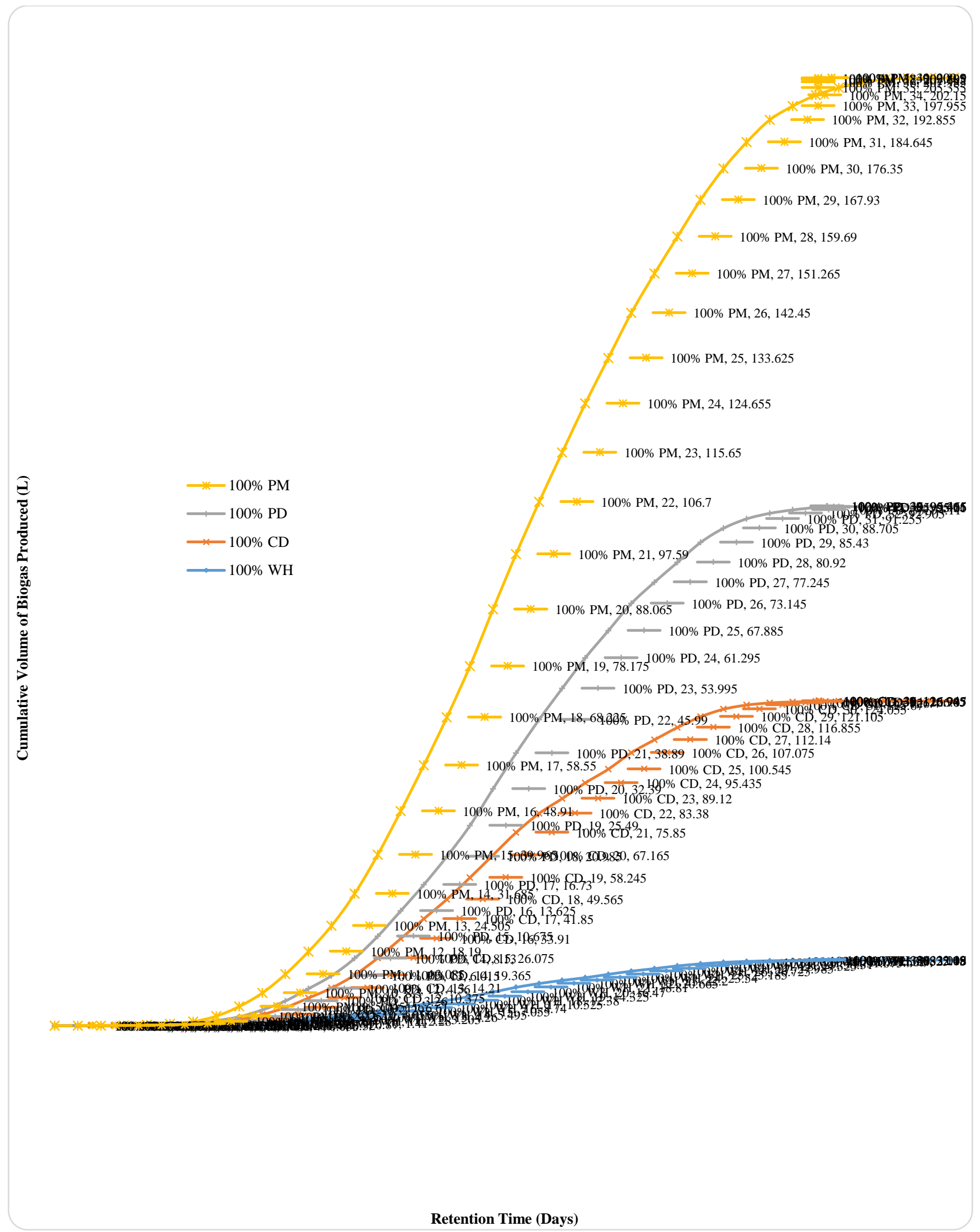

Figure 1. Cumulative biogas yield for single-substrate digestion 


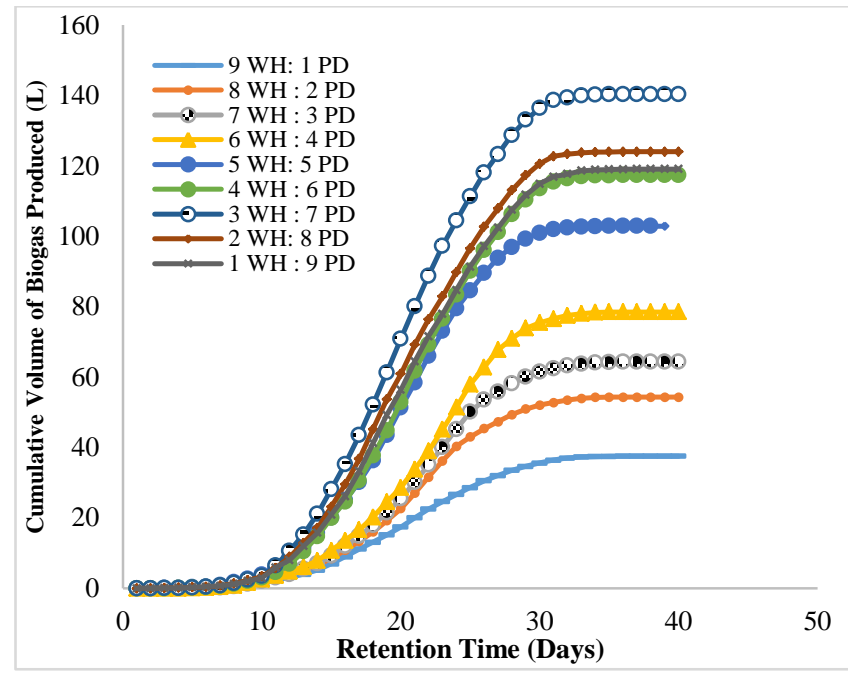

Figure 2. Cumulative biogas yield for PD-aided WH digestion

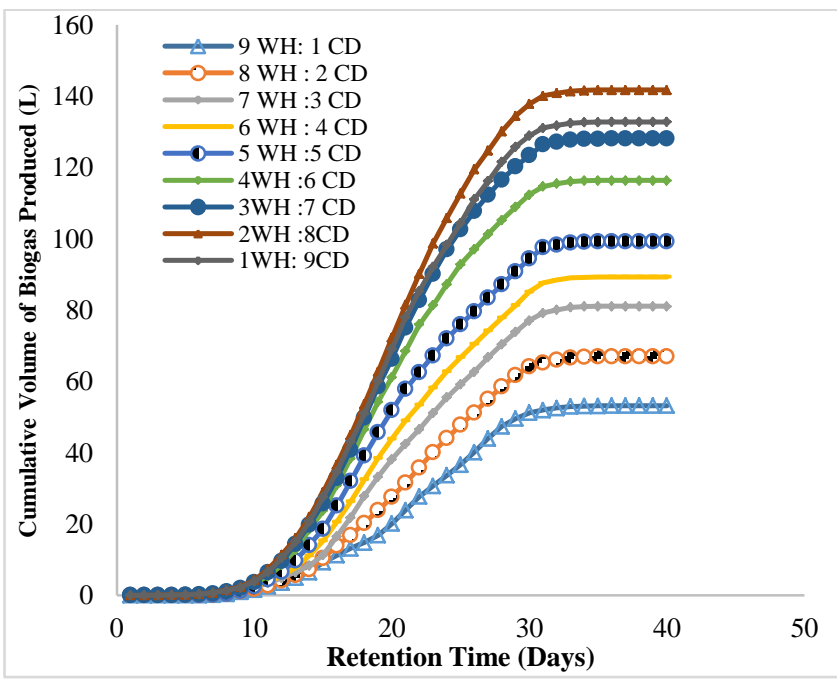

Figure 3. Cumulative Biogas yield for CD-aided $\mathrm{WH}$ digestion

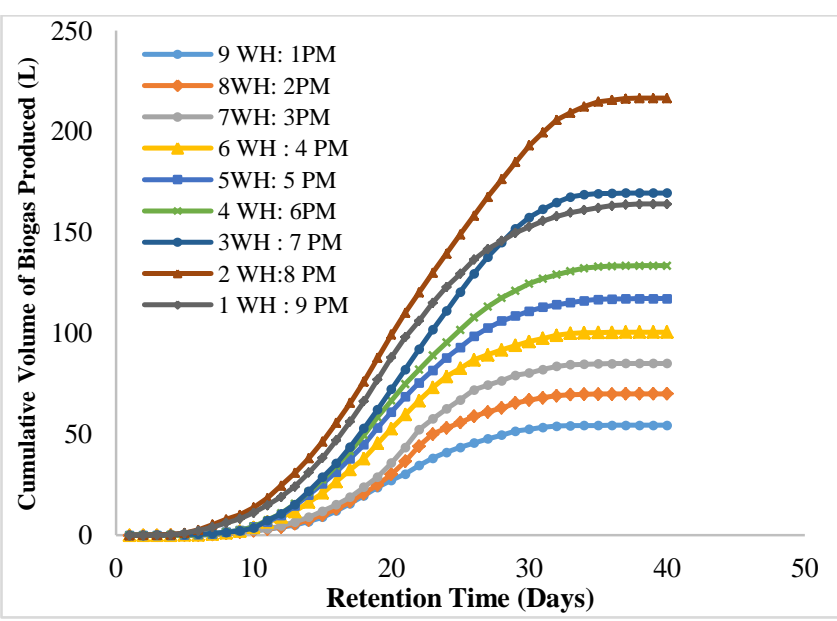

Figure 4. Cumulative Biogas yield for PM-aided $\mathrm{WH}$ digestion

\section{Relationship between Independent variables and cumulative volume of gas produced}

The relationship between the cumulative volume of gas produced by the three best mixes of animal aided $\mathrm{WH}$ digestion and the independent variables were determined using multiple regression and the results are presented in Tables 3, 4 and 5 .

Table 3. Estimates of multiple regression analysis for the PD-aided WH digestion

\begin{tabular}{lcccc}
\hline Variables & Coefficient & $\begin{array}{c}\text { Std. } \\
\text { Error }\end{array}$ & $\mathbf{t}_{\text {value }}$ & Sig. \\
\hline $\begin{array}{l}\text { (Constant) } \\
\begin{array}{l}\text { Retention Time } \\
\text { (Days) }\end{array}\end{array}$ & -250.107 & 81.210 & -3.080 & 0.004 \\
$\begin{array}{l}\text { Hydrogen Ion } \\
\text { Concentration } \\
(\mu \text { mol/L) }\end{array}$ & 160.169 & 41.790 & 3.833 & 0.001 \\
$\begin{array}{l}\text { Temperature }\left({ }^{\circ} \mathrm{C}\right) \\
\begin{array}{l}\text { Biogas Pressure } \\
\text { (bar) }\end{array}\end{array}$ & 6.715 & 2.567 & 2.616 & 0.0001 \\
\hline $\mathrm{R}^{2}=0.956 ;$ Adjusted $\mathrm{R}^{2}=0.950 ; \mathrm{F}_{\text {value }}=188.125 ;$ Prob $>\mathrm{F}=0.000$ & & & 0.754 \\
\hline
\end{tabular}

From the regression results presented in Table 3, the $\mathrm{R}^{2}$ value of 0.956 implies that $95.6 \%$ of the variations in the cumulative volume of gas produced in the PD-aided WH digestion is accounted for by variations in the four variables put together. This implies that the retention time, hydrogen ion concentration of the substrates, temperature within the digester and pressure of the gas produced were able to explain the behavior of the cumulative gas produced by the mix ratio at $95.6 \%$ level of confidence. The adjusted $\mathrm{R}^{2}$ value further supported the claim with a value of 0.950 or $95.0 \%$. The $\mathrm{F}$ value of 188.125 at prob > $\mathrm{f}$ of 0.000 shows that the entire regression is significant at less than $1 \%$ probability level. On the individual variables, the results show that the retention time, hydrogen ion concentration and temperature are statistically significant at $5 \%$ probability level and positively related with the cumulative gas produced. Temperature is one of the main factors affecting performance and stability of anaerobic digestion process (Labatut et al., 2014 and Ziganshi et al., 2013). From the experimental results, at higher temperature decomposition take place quickly and hence, the volume of gas produced increased, ultimately increasing the cumulative volume of gas. On the other hand, the pressure of the gas is positively related to the cumulative volume of the gas produced but not statistically significant. This implies that an increase in the pressure of the gas coming from the digester will lead to a corresponding increase in the cumulative volume of gas 
produced. The equation for cumulative volume of gas produced by the PD-aided WH digestion can be written as shown in equation 5

$\mathrm{Y}=-250.107+3.928 \mathrm{X}_{1}+160.169 \mathrm{X}_{2}+6.175 \mathrm{X}_{3}+1.358$

$\mathrm{X}_{4}+\mathrm{E}$.

Table 4. Estimates of multiple regression analysis for the CD-aided WH digestion

\begin{tabular}{lcccc}
\hline Variables & Coefficient & $\begin{array}{c}\text { Std. } \\
\text { Error }\end{array}$ & $\mathbf{t}_{\text {value }}$ & Sig. \\
\hline $\begin{array}{l}\text { (Constant) } \\
\text { Retention Time } \\
\text { (Days) }\end{array}$ & -274.813 & 37.958 & -7.240 & 0.0001 \\
$\begin{array}{l}\text { Hydrogen Ion } \\
\begin{array}{l}\text { Concentration } \\
(\mu \text { mol/L) }\end{array}\end{array}$ & 153.143 & 19.689 & 7.778 & 0.0001 \\
$\begin{array}{l}\text { Temperature }\left({ }^{\circ} \mathrm{C}\right) \\
\begin{array}{l}\text { Biogas Pressure } \\
\text { (bar) }\end{array}\end{array}$ & 7.301 & 1.232 & 5.924 & 0.0001 \\
\hline $\mathrm{R}^{2}=0.979 ;$ Adjusted $\mathrm{R}^{2}=0.977 ; \mathrm{F}_{\text {value }}=409.544 ;$ Prob $>\mathrm{F}=0.000$ & 0.0001 \\
\hline
\end{tabular}

Table 4 shows that an $\mathrm{R}^{2}$ value of 0.979 was observed for the CD-aided WH digestion. This implies that $97.9 \%$ of the variations in the cumulative volume of gas produced in the CD-aided WH digestion is accounted for by variations in the four independent variables put together. In other words, the independent variables were sufficient to explain the behavior of the dependent variable at $97.9 \%$ level of confidence. This claim is supported by an adjusted $\mathrm{R}^{2}$ value of $97.7 \%$. The entire regression is significant at less than $1 \%$ probability level with a $F$ value of 409.544 at prob $>\mathrm{f}$ of 0.000 . The results also show that the retention time, hydrogen ion concentration and temperature are statistically significant at $5 \%$ probability level and positively related with independent variable. While the pressure of the gas is positively related to the cumulative volume of the gas produced but not statistically significant. The equation for cumulative volume of gas produced by the $\mathrm{CD}$-aided $\mathrm{WH}$ digestion can be written as shown in equation 6 .

$\mathrm{Y}=-274.813+3.955 \mathrm{X}_{1}+153.143 \mathrm{X}_{2}+7.301 \mathrm{X}_{3}+4.217$ $\mathrm{X}_{4}+\mathrm{E}$

An $\mathrm{R}^{2}$ value of 0.969 was observed for the PM-aided WH digestion as observed in Table 5. This means that $96.9 \%$ of the variations in the cumulative volume of gas produced in the PM-aided WH digestion is accounted for by variations in the four variables put together. The independent variables were sufficient to explain the behavior of the dependent variable at level of confidence.
This claim is reinforced by an adjusted $\mathrm{R}^{2}$ value of $96.6 \%$. The whole regression is significant at less than $1 \%$ probability level with a $\mathrm{F}$ value of 276.488 at prob $>\mathrm{f}$ of 0.000 . The results also revealed that the retention time and hydrogen ion concentration are statistically significant at $5 \%$ probability level and positively related with independent variable. While the temperature within the digester and the pressure of the gas produced is positively related to the cumulative volume of the gas produced but not statistically significant. The equation for cumulative volume of gas produced by the PM-aided WH digestion can be written as shown in equation 7 .

$\mathrm{Y}=-151.162+5.704 \mathrm{X}_{1}+80.505 \mathrm{X}_{2}+2.586 \mathrm{X}_{3}+7.445$

$\mathrm{X}_{4}+\mathrm{E}$

Table 5. Estimates of multiple regression analysis for the PM-aided WH digestion

\begin{tabular}{lcccc}
\hline Variables & Coefficient & $\begin{array}{c}\text { Std. } \\
\text { Error }\end{array}$ & $\mathbf{t}_{\text {value }}$ & Sig. \\
\hline $\begin{array}{l}\text { (Constant) } \\
\text { Retention Time }\end{array}$ & -151.162 & 99.139 & -1.525 & .136 \\
(Days) & 5.704 & 0.307 & 18.585 & 0.0001 \\
$\begin{array}{l}\text { Hydrogen Ion } \\
\text { Concentration } \\
(\mu \text { mol/L) }\end{array}$ & 80.505 & 20.863 & 3.859 & 0.0001 \\
$\begin{array}{l}\text { Temperature }\left({ }^{\circ} \mathrm{C}\right) \\
\begin{array}{l}\text { Biogas Pressure } \\
\text { (bar) }\end{array}\end{array}$ & 2.586 & 3.142 & 0.823 & 0.416 \\
\hline $\mathrm{R}^{2}=0.969 ;$ Adjusted $\mathrm{R}^{2}=0.966 ; \mathrm{F}_{\text {value }}=276.488 ;$ Prob $>\mathrm{F}=0.000$
\end{tabular}

\section{CONCLUSION}

An appraisal of the cumulative volume of gas produced from different co-digestion mixes of $\mathrm{WH}$ and selected animal dungs was done in terms of retention time, hydrogen ion concentration, temperature and biogas pressure. Equations were derived to show the relationship between the cumulative volume of gas produced and the aforementioned variables. At the end of the study, three best mixes of WH to the animal dungs were obtained. From the results obtained the best mix of the PD-aided WH digestion is $3 \mathrm{WH}: 7 \mathrm{PD}$ with a $140.32 \mathrm{~L}$ cumulative volume of biogas produced. For the $\mathrm{CD}$ - aided $\mathrm{WH}$ digestion, the best mix is $2 \mathrm{WH}: 8 \mathrm{CD}$ with a cumulative volume of $141.72 \mathrm{~L}$ of biogas produced and for the PMaided WH digestion, the best mix is $2 \mathrm{WH}$ : 8 PM with a cumulative biogas volume of $216.55 \mathrm{~L}$ produced. The study revealed that the PM - aided WH mix produced more biogas when compared to the $\mathrm{CD}$ and $\mathrm{PD}$ aided $\mathrm{WH}$ digestion mixes. 


\section{DECLARATIONS}

\section{Corresponding author}

E-mail: omojo@futa.edu.ng ; ORCID: 0000-00021113-0359

\section{Acknowledgements}

The authors would like to acknowledge the Federal University of Technology, Akure for creating a conducive environment to conduct this research.

\section{Authors' contribution}

OM Ojo performed the experiments, analysed the data obtained and wrote the manuscript. JO Babatola designed the experimental process and revised the manuscript. Both authors read and approved the final manuscript

\section{Conflict of interest}

The authors hereby confirm that there is no conflict of interest whatsoever with any third party.

\section{REFERENCES}

Al-Imam MFI, Khan MZH, Sarkar MAR, Ali SM.(2013). Development of biogas processing from cow dung, poultry waste, and water hyacinth. International Journal of Natural and Applied Science, 2(1): 13-17. Google Scholar

Arogo JO, Wen Z; Ignosh J, Bendfeldt EM, Collins ER. (2009). Biomethane Technology. College of Agriculture and Life Sciences, Virginia Polytechnic Institute and State University, Virginia. pp 442-881. Google Scholar; http://hdl.handle.net/10919/50131

Atkins M, Fuchs M, Hoffman A, Wilhelm N. (2008). Plastic Tubular Biogas Digesters: A Pilot Project in Uru, Kilimanjaro, Tanzania. Google Scholar

Bouallagui H, Lahdheb H; E. Ben Romdan E, Rachdi B, Hamdi M. (2009). Improvement of fruit and Vegetable waste anaerobic digestion performance and stability with cosubstates addition. Journal of Environmental Management, 90(5):1844-1849. https://doi.org/10.1016/j.jenvman.2008.12.002

Budiyono IN, Widiasa S, Johari S. (2010). The kinetic of biogas production rate from cattle manure in batch mode. International Journal of Chemical and Molecular Engineering. $\quad 4(1)$ : 75-80. Link; https://doi.org/10.5281/zenodo.1074968

Bujoczek G, Oleszkiewicz J, Sparling R, Cenkowski S. (2000). High solid anaerobic digestion of chicken manure. Journal of Agricultural Engineering Research, 76(1): 51-60. https://doi.org/10.1006/jaer.2000.0529

Castrillon L,Vazguez I, Maranon E,Satre H. (2002). Anaerobic thermophilic treatmentof cattle manure in UASB reactors. Waste Management and Research. 20(4): 350-356. https://doi.org/10.1177/0734247X0202000406

Gelegenis J, Georgakakis D, Angelidaki I, Mavris V. (2007). Optimization of biogas production by co-digesting whey with diluted poultry manure. Renewable Energy,
32(13):

$2147-2160$

https://doi.org/10.1016/j.renene.2006.11.015

Itodo IN, Kucha EI. (1998). An empirical relationship for predicting biogas yield from poultry waste slurry. Nigerian Journal of Renewable Energy, 1: 31-37. Google Scholar

Katima JHY. (2001). Production of biogas from water hyacinth: Effect of substrate concentration, particle size and incubation period. Tanzania Journal of Science, 27(1): 107119. https://doi.org/10.4314/tjs.v27i1.18340

Kivaisi AK, Mtila M. (1997). Production of biogas from water hyacinth (Eichhornia crassipes) (Mart) (Solms) in a twostage bioreactor. World Journal of Microbiology and Biotechnology, 14(1): 125-131. https://doi.org/10.1023/A:1008845005155

Kivaisi AK. (2002). Pretreatment of robusta coffee hulls and codigestion with cow-dung for enhanced anaerobic digestion. Tanzania Journal of Science, 28(2):1-10. https://doi.org/10.4314/tjs.v28i2.18349

Labatut RA, Angenent LT, Scott NR. (2014). Conventional mesophilic vs. thermophilic anaerobic digestion: a trade-off between performance and stability? Water Research, 53: 249-258. https://doi.org/10.1016/j.watres.2014.01.035

Li, R, Chen S, Li X. (2009). Anaerobic codigestion of kitchen waste and cattle manure formethane production. Energy Sources, $\quad 31(20)$ : 1848-1856. https://doi.org/10.1080/15567030802606038

Malik A. (2007). Environmental challenge vis a vis opportunity: The case of water hyacinth. Environment International, 33(1): 122-138. https://doi.org/10.1016/j.envint.2006.08.004

Nnabuchi MN,Akubuko FO, Augustine C,Ugwu GZ. (2012). Assessment of the Effect of Co-Digestion of Chicken Dropping and Cow Dung on Biogas Generation. Global Journal of Science Frontier Research, 12 (7): 20-26. Google $\underline{\text { Scholar }}$

Ofoefule AU, Uzodinma EO, Anyanwu CN. (2010). Studies on the effect of Anaerobic Digestion on the microbial flora of Animal Wastes: Digestion and Modelling of Process Parameters. Trends in Applied Sciences Research. 5 (1): 3947. https://doi.org/10.3923/tasr.2010.39.47

Ojo OM, Babatola JO, Akinola AO. (2018). Regression Analysis of Biogas Production from the Co-Digestion of Water Hyacinth and Pig Dung. FUOYE Journal of Engineering $\begin{array}{lll}\text { and } & \text { Technology. } & 3(2):\end{array}$ https://doi.org/10.46792/fuoyejet.v3i2.267

Ojo OM. (2017). Biomethanation of Water Hyacinth and Selected Animal Dungs for Biogas Production. Unpublished Ph.D Thesis in the Department of Civil Engineering, The Federal University of Technology, Akure. Google Scholar

Ojolo SJ, Oke SA, Animasahun OK, Adesuyi BK. (2007). Utilization of poultry, cow and kitchen wastes for biogas production: A comparative analysis. Iranian Journal of EnvironmentalHealth Science and Engineering, 4(4): 223228. https://ijehse.tums.ac.ir/index.php/jehse/article/view/136

Pachaiyappan S, Elamvazhuthi P,Dhamodharan M, Seshadri S. (2014). Biogas production from water hyacinth blended with cow dung. Indian Journal of Energy, 3(1): 134-139. $\underline{\text { Google Scholar }}$ 
Patil JH, Molayan AR, Bhargav S, Sowmya SR. (2011). Anaerobic co-digestion of water hyacinth with primary sludge, Research Journal of Chemical Science, 1(3):72-77. Google Scholar

Perna C, Burrows D. (2005). Improved dissolved oxygen status following removal of exotic weed in important fish habitat lagons of the tropical Burdekin Riva floodplain, Australia, Marine Pollution Bulletin. 2005 Jan 1;51(1-4):138-48. https://doi.org/10.1016/j.marpolbul.2004.10.050

Sadaka S, Engler C. (2000). Effects of mixing on anaerobic composting of beef manure. In:Proceeding of ASAE Annual International Meeting, Technical papers: EngineeringSolutions for a New Century, 9-12 July, pp. 4993-5001. $\underline{\text { CAB Direct }}$
Yusuf MO, Debora A, Ogheneruona DE. (2011). Ambient temperature kinetic assessment of biogas production from co-digestion of horse and cow dung. Research in Agricultural Engineering. 57(3): 97-104. https://doi.org/10.17221/25/2010-RAE

Zamudio CEM. (2010). Technical Feasibility of Anaerobic Codigestion of Dairy Manure with Chicken Litter and Other Wastes. Master's Thesis, University of Tennessee. Available online at http://trace.tennessee.edu/utk_gradthes/676 ; Google Scholar

Ziganshin, AM, Liebetrau J, Pröter J, Kleinsteuber S. (2013). Microbial community structure and dynamics during anaerobic digestion of various agricultural waste materials. Applied Microbiology Biotechnology, 97(11): 5161 - 5174. https://doi.org/10.1007/s00253-013-4867-0 